\title{
UJI KANDUNGAN PENCEMARAN TIMBAL PADA HASIL LAUT DI KABUPATEN BANYUWANGI
}

\section{TEST OF LEAD POLLUTION CONTENT IN SEA PRODUCTS IN BANYUWANGI REGENCY}

\author{
Offa Afrilla*, Septa Indra Puspikawati \\ Departemen Kesehatan Lingkungan, Program Studi Kesehatan Masyarakat, Fakultas Kesehatan \\ Masyarakat PSDKU Universitas Airlangga, Banyuwangi \\ Jl. Wijayakusuma No.113, 68425, Banyuwangi, Jawa Timur, Indonesia \\ *email: offa.afrilla-2017@fkm.unair.ac.id
}

\begin{abstract}
Lead metal pollution has an impact on human health such as damage during the formation of erythrocytes and the accumulative nature of heavy metals so that if it enters the body it will cause longterm effects. The purpose of this study was to quantitatively measure the lead content in food. This research methodology is descriptive observational in which the researcher used the Pb Rapid Test kit which was carried out at the Environmental Health Laboratory of the Airlangga University PSDKU in Banyuwangi on February 18, 2020. The population of this study was all samples in the form of seafood and canned foods. Samples were taken randomly on 15 traders who were in traditional markets, each 1 trader was taken 1 sample using a total sampling of 15 samples. The results showed that there was 1 sample containing lead, namely shrimp paste that obtained Pb test results with a level of $20 \mathrm{mg} / \mathrm{l} \mathrm{Pb^{2 }}$ ${ }^{+}$while the other 14 samples were still within safe limits, namely the results of the Pb strip test with a level of $0 \mathrm{mg} / 1 \mathrm{~Pb}^{2+}$. The Pb yield in shrimp paste exceeds the maximum limit of $1.0 \mathrm{mg} / \mathrm{kg}$ in accordance with the regulation of the Head of the Food and Drug Administration of the Republic of Indonesia Number HK.00.06.1.52.4011 in 2009. The conclusion of this study is based on these results, the government, the industrial sector. food and consumers are expected to work together to prevent the negative impact on the body due to lead metal in food.
\end{abstract}

Keyword: Food, Heavy Metals, Lead

\begin{abstract}
Abstrak
Pencemaran logam timbal berdampak bagi kesehatan manusia seperti kerusakan saat pembentukan eritrosit dan sifat logam berat yang akumulatif sehingga jika masuk ke dalam tubuh akan menimbulkan efek jangka panjang. Tujuan penelitian ini adalah untuk mengukur kadar timbal pada makanan secara kuantitatif. Metodologi penelitian ini bersifat observasional deskriptif dimana peneliti menggunakan alat Rapid Test Kit Pb yang dilaksanakan di Laboratorium Kesehatan Lingkungan PSDKU Universitas Airlangga di Banyuwangi pada tanggal 18 Februari 2020. Populasi penelitian ini adalah seluruh sampel berupa makanan jenis hasil laut dan makanan kaleng. Pengambilan sampel dilakukan secara acak pada 15 pedagang yang berada di pasar tradisional, tiap 1 pedagang diambil 1 sampel dengan menggunakan total sampling yaitu sebanyak 15 sampel. Hasil penelitian menunjukkan bahwa terdapat 1 sampel yang mengandung timbal yaitu pada terasi udang yang memperoleh hasil test strip $\mathrm{Pb}$ dengan kadar $20 \mathrm{mg} / \mathrm{l}$ $\mathrm{Pb}^{2+}$ sedangkan 14 sampel lainnya masih berada dalam batas aman yaitu hasil test strip $\mathrm{Pb}$ dengan kadar $0 \mathrm{mg} / 1 \mathrm{~Pb}^{2+}$. Hasil $\mathrm{Pb}$ pada terasi udang melebihi batas maksimum yaitu sebesar $1,0 \mathrm{mg} / \mathrm{kg}$ sesuai dengan peraturan Kepala Badan Pengawas Obat dan Makanan Republik Indonesia Nomor HK.00.06.1.52.4011 tahun 2009. Saran bagi pemerintah, bidang industri pangan dan konsumen
\end{abstract}


diharapkan dapat bekerjasama untuk mencegah dampak negatif terhadap tubuh akibat logam timbal pada makanan.

Kata Kunci: Logam Berat, Makanan, Timbal

\section{PENDAHULUAN}

Kesehatan adalah keadaan sejahtera fisik, mental dari sosial yang memungkinkan setiap orang produktif dalam menjalankan aktivitasnya. Kondisi sehat sebagai alat untuk melakukan kegiatan yang lebih produktif (UU No. 36 Tahun 2009). Pencemaran logam berat memberikan dampak bagi lingkungan hidup dan kesehatan. Logam berat akan membahayakan jika masuk ke dalam tubuh dengan kadar melebihi batas maksimum yang telah ditetapkan pada SNI 7387:2009 tentang Batas Maksimum Cemaran Logam Berat dalam Pangan. Efek racun dari logam berat akan menimbulkan kerusakan ekologis yang serius karena sifat kelarutan dan mobilitasnya. Hal ini juga diperkuat oleh Siripongvutikorn et al., (2016) bahwa logam berat akan menimbulkan efek kesehatan di dalam jaringan organ tubuh terutama di dalam organ limpa, pankreas, hati, dan lambung. Perairan atau lautan berpotensi mengandung logam berat karena berbatasan dengan daratan. Hal ini mangakibatkan masyarakat yang tinggal di daerah pantai akan mudah beresiko karena bahan makanan yang terkontaminasi dengan logam berat (Setiawan, 2015).

Setyaningrum et al., (2018) menyatakan bahwa logam berat yang memberikan efek racun bagi tubuh yaitu logam timbal $(\mathrm{Pb})$. Menurut penelitian Indirawati (2017) pencemaran logam timbal berdampak bagi kesehatan manusia seperti kerusakan saat pembentukan eritrosit. Logam berat bersifat akumulatif dan apabila masuk ke dalam tubuh akan menimbulkan efek jangka panjang. Sumber utama pencemaran timbal di perairan yaitu limbah dan emisi dari industri, kendaraan yang menggunakan bensin bertimbal, asap dan debu, emisi PLT batu bara, dan gas (Lee et al., 2017).

Timbal meruapakan kontaminan lingkungan dari bahan kimia dan fisik yang memberikan efek pada ekosistem. Kehadiran logam timbal di laut disebabkan oleh erosi dan muncul dari pengendapan debu timbal di atmosfer karena penggunaannya yang luas seperti cat industri, drum, pipa dan aditif dalam produk minyak bumi (Santos et al., 2014). Jika mengkonsumsi makanan yang terkontaminasi logam timbal dan sudah terakumulasi di dalam darah, maka akan menimbulkan efek samping, seperti Intelligence Quotients (IQ) berkurang bagi anak-anak, masalah perilaku, kardiovaskular, dan toksisitas ginjal pada orang dewasa (Kirinčič et al., 2019)

Keamanan pangan yang rendah akan memberikan dampak kesehatan bagi orang yang mengkonsumsi makanan tersebut. Beberapa penelitian tentang analisis timbal pada makanan, menyimpulkan bahwa kandungan timbal tertinggi pada terasi bermerek sebesar 1,80 $\mathrm{mg} / \mathrm{kg}$ dan terasi tidak bermerek sebesar 1,88 $\mathrm{mg} / \mathrm{kg}$ yakni melewati batas maksimum yang telah ditentukan yaitu $1,0 \mathrm{mg} / \mathrm{kg}$ (Angkat et al., 2013). Penelitian Eshmat et al., (2014) juga menyimpulkan bahwa kandungan logam berat timbal pada kerang hijau dengan nilai timbal tertinggi pada ST1 yaitu $0,871 \mathrm{ppm}$. Penelitian lain oleh Nurjanah et al., (2012) menunjukkan bahwa kandungan timbal selama Bulan Mei pada kijing (kerang) kecil sebesar 1,49 ppm dan pada kijing (kerang) besar sebesar 1,71 ppm. Pada Bulan Juli ditemukan sebesar 1,19 ppm pada kijing kecil dan 1,17 ppm pada kijing besar. Hasil penelitian oleh Putri et al., (2019) menunjukkan bahwa kandungan timbal pada udang putih berkisar antara $0,711 \mathrm{mg} / \mathrm{kg}-0,932$ $\mathrm{mg} / \mathrm{kg}$, yakni melebihi batas maksimum sebesar $0,5 \mathrm{mg} / \mathrm{kg}$. Selanjutnya, penelitian oleh Apriyanti (2018) menunjukkan bahwa kandungan timbal pada 5 sampel kerang Polymesoda erosa $L$ sebesar antara $1,07 \mathrm{mg} / \mathrm{kg}$ hingga $2,05 \mathrm{mg} / \mathrm{kg}$ yakni melebihi ambang batas.

Berdasarkan penjelasan tersebut, pemerintah perlu melakukan pengawasan yang lebih ketat terhadap keamanan pangan, Pengawasan makanan dapat dilakukan oleh BPOM (Badan Pengawasa Obat dan Makanan). Menurut Peraturan Kepala BPOM RI Nomor 23 Tahun 2017 tentang Batas Maksimum Cemaran Logam Berat dalam Pangan Olahan adalah bahan yang tidak sengaja ada dan/atau tidak dikehendaki dalam pangan yang berasal dari lingkungan atau sebagai akibat proses di sepanjang rantai pangan, baik berupa cemaran biologis, cemaran kimia, residu obat hewan, dan pestisida maupun benda lain yang dapat 
mengganggu, merugikan, dan membahayakan kesehatan manusia (Badan Pengawas Obat dan Makanan RI, 2017).

Menurut Sari (2019) salah satu daerah yang perlu pengawasan adalah Banyuwangi karena Banyuwangi menjadi daerah wisata yang mudah menarik wisatawan lokal maupun internasional dengan keindahan laut dan alam yang ada. Menurut Yona et al., (2018) Banyuwangi merupakan wilayah yang memiliki beragam aktifitas manusia seperti industri perikanan, pelabuhan dan tempat wisata. Aktifitas tersebut dapat menimbulkan potensi masuknya polutan logam berat ke perairan di Banyuwangi. Hal ini diperkuat oleh penelitian Setyaningrum et al., (2018) bahwa Banyuwangi yang berada di Selat Bali mempunyai kelautan atau potensi pesisir yang cukup tinggi. Hal ini sangat mengkhawatirkan karena organisme laut akan tercemar oleh logam berat dari aliran sungai atau limbah yang berasal dari pabrik. Hasil olahan laut yang berasal dari perairan Banyuwangi nantinya akan dikonsumsi oleh masyarakat.

Penelitian ini mengambil sampel makanan pada beberapa pasar tradisional yang terdapat di Banyuwangi, yaitu Pasar Banyuwangi, Pasar Blambangan, Jalan Kalilo dan Rogojampi. Lokasi ini memiliki lalu lintas yang padat karena berdekatan dengan tempat wisata pantai-pantai, Taman Blambangan dan toko-toko. Padatnya kendaraan menyebabkan tingginya polusi yang mengakibatkan timbulnya timbal pada makanan. Selain itu, tempat yang dekat dengan pantai juga menyebabkan makanan terkontaminasi timbal (Perdana et al., 2016). Oleh karena itu penelitian ini bertujuan untuk mengetahui ada tidaknya kadar $\mathrm{Pb}$ pada makanan yang diperjualbelikan di beberapa pasar tradisional di Banyuwangi.

\section{METODE PENELITIAN}

Penelitian ini dilaksanakan di ruang Laboratorium Kesehatan Lingkungan PSDKU Universitas Airlangga di Banyuwangi pada tanggal 18 Februari 2020 dengan metode penelitian observasional deskriptif. Jenis penelitian ini adalah penelitian laboratorium dengan pengujian kandungan timbal pada sampel makanan. Sampel penelitian ini ialah makanan jenis olahan laut dan makanan kaleng. Penelitian ini menggunakan total sampling yaitu sebanyak 15 sampel. Sampel diambil di tempat penjual dan pasar tradisional di Banyuwangi. Pengambilan sampel dilakukan secara acak pada
15 pedagang yang berada di pasar tradisional, tiap 1 pedagang diambil 1 sampel.

Pengujian sampel makanan dilakukan sesuai dengan prosedur menggunakan alat Rapid Test Kit $\mathrm{Pb}$ (4 botol reagen pereaksi timbal, 2 tabung reaksi kaca, petunjuk prosedur pengujian, larutan standar $\mathrm{Pb}$ ). Bahan yang digunakan pada penelitian ini adalah air (aquadest/air bersih) dan sampel makanan. Alat yang digunakan dalam penelitian ini adalah mortar dan pestle, pipet, gelas beker, ATK (Alat Tulis Kantor), APD (Alat Pelindung Diri) seperti masker dan handscoon, kamera, rapid tes kit untuk Lead/Pb, pisau, talenan dan timbangan.

Prosedur pengujian timbal adalah sebagai berikut:

1. Siapkan alat dan bahan dalam kondisi steril;

2. Iris sampel menjadi potongan kecil;

3. Ambil potongan sampel kira-kira 10 gram lalu letakkan dan kemudian haluskan di mortar dengan pestle;

4. Tambahkan aquadest secukupnya;

5. Ambil ekstrak sampel dengan menggunakan pipet sebanyak $5 \mathrm{ml}$ dari murtal dan letakkan di gelas beker;

6. Cek dengan menggunakan $\mathrm{pH}$ indicator strips dalam gelas beker;

7. Apabila hasilnya melebihi 5, maka tambahkan 3 tetes cairan $\mathrm{Pb}$ sehingga hasil kurang atau sama dengan 5. Apabila sudah ditambahkan tetes cairan $\mathrm{Pb}$, kemudian digoyangkan;

8. Uji $\mathrm{Pb}$ dengan cara mencelupkan kertas uji $\mathrm{Pb}$ ke dalam cairan dalam gelas beker;

9. Celupkan zone reaksi pada test strips ke dalam sampel selama 1 detik;

10. Keringkan larutkan pada strip selama 2 menit, kemudian bandingkan warna tersebut dengan skala warna pada tabung; Tentukan warna yang paling mendekati skala warna.

Hasil pengujian kadar timbal kemudian dibandingkan dengan batas maksimum cemaran logam sesuai standar yang ditetapkan oleh Direktorat Jenderal Pengawasan Obat dan Makanan No. 00.06.1.52.4011 Tahun 2009 dan SNI 7387:2009 tentang Batas Maksimum Cemaran Logam Berat dalam Pangan. Data khusus yang diambil meliputi kadar $\mathrm{Pb}$ pada makanan di Pasar Blambangan, Rogojampi, Jalan Kalilo, dan Pasar Banyuwangi. Data hasil penelitian berupa kadar $\mathrm{Pb}$ dalam makanan yang diperoleh dengan test kit untuk $\mathrm{Pb}$ akan dianalisis secara deskriptif. 


\section{HASIL DAN PEMBAHASAN}

Berdasarkan hasil pengujian timbal pada makanan menunjukkan bahwa terdapat 1 dari 15 sampel makanan yang mengandung timbal dan tidak sesuai dengan peraturan Kepala Badan Pengawas Obat dan Makanan Republik Indonesia Nomor HK.00.06.1.52.4011 tahun 2009 tentang Penetapan Batas Maksimum Cemaran Mikroba dan Kimia dalam Makanan. Hasil pengujian terhadap kandungan Timbal $(\mathrm{Pb})$ pada beberapa sampel dan disajikan dalam Tabel 1.

Tabel 1. Hasil Pengamatan Uji Timbal (Pb)

\begin{tabular}{|c|c|c|c|c|}
\hline \multirow[b]{2}{*}{$\begin{array}{c}\text { Jenis } \\
\text { Makanan }\end{array}$} & \multicolumn{2}{|c|}{$\begin{array}{c}\text { Perubahan } \\
\text { pH }\end{array}$} & \multirow{2}{*}{$\begin{array}{c}\text { Hasil } \\
\text { Test } \\
\text { Strip } \\
\mathbf{P b} \\
(\mathbf{m g} / 1 \\
\left.\mathbf{P b}^{2+}\right)\end{array}$} & \multirow[b]{2}{*}{ Hasil } \\
\hline & $\begin{array}{c}\text { pH } \\
\text { Awal }\end{array}$ & $\begin{array}{c}\text { pH } \\
\text { Akhir }\end{array}$ & & \\
\hline Kerang kijing & 5 & - & 0 & Negatif \\
\hline $\begin{array}{l}\text { Ikan } \\
\text { mernying } \\
\text { (Pasar } \\
\text { Blambangan) }\end{array}$ & 5 & - & 0 & Negatif \\
\hline Ikan laut & 6 & 5 & 0 & Negatif \\
\hline Terasi udang & 7 & 7 & 20 & Positif \\
\hline Tempura & - & - & 0 & Negatif \\
\hline Cumi-cumi & 5 & - & 0 & Negatif \\
\hline Kupang & - & - & 0 & Negatif \\
\hline $\begin{array}{l}\text { Ikan } \\
\text { mernying } \\
\text { (Rogojampi) }\end{array}$ & 6 & 5 & 0 & Negatif \\
\hline $\begin{array}{l}\text { Ikan } \\
\text { mernying }\end{array}$ & 6 & 5 & 0 & Negatif \\
\hline $\begin{array}{l}\text { Kerang (Pasar } \\
\text { Banyuwangi) }\end{array}$ & 6 & 5 & 0 & Negatif \\
\hline $\begin{array}{l}\text { Pindang } \\
\text { melijo }\end{array}$ & 6 & 5 & 0 & Negatif \\
\hline Ikan sarden & 5 & - & 0 & Negatif \\
\hline Kerang & 6 & 5 & 0 & Negatif \\
\hline Udang putih & 6 & 5 & 0 & Negatif \\
\hline Ikan tuna & 5 & - & 0 & Negatif \\
\hline
\end{tabular}

Tabel 1 menunjukkan bahwa berdasarkan pengujian kandungan timbal $(\mathrm{Pb})$ dalam makanan didapatkan hasil dari 15 sampel pengujian, terdapat 1 sampel yang mengandung timbal dan 14 sampel tidak mengandung timbal. Sampel makanan yang mengandung timbal yaitu pada terasi udang yang dibeli di mlijoan Jalan Kalilo dimana memperoleh hasil test strip $\mathrm{Pb}$ dengan kadar $20 \mathrm{mg} / 1 \mathrm{~Pb}^{2+}$. Hasil tersebut melebihi batas maksimum yaitu sebesar 1,0 $\mathrm{mg} / \mathrm{kg}$ sesuai dengan peraturan Kepala Badan Pengawas Obat dan Makanan Republik Indonesia Nomor HK.00.06.1.52.4011 tahun 2009. Berdasarkan 15 sampel makanan, terdapat sampel yang memiliki kemasan hanya berupa plastik biasa yaitu kerang kijing, ikan mernying, ikan laut, tempura, cumi-cumi, terasi udang, kupang, kerang, pindang melijo, dan udang putih yang didapatkan dari beberapa pasar tradisional. Kemasan ikan tuna dan ikan sarden berupa kaleng dan didapatkan di toko swalayan.

Selaras dengan penelitian Ummi et al., (2017) bahwa hasil penelitian kandungan timbal pada 4 sampel terasi udang positif mengandung timbal yang melebihi ambang batas. Kadar tertinggi dengan kode T1 (produksi U) sebesar $8,84 \pm 0,12 \mathrm{mg} / \mathrm{kg}$, T2 (produksi S) sebesar 5,14 $\pm 0,13 \mathrm{mg} / \mathrm{kg}$, T3 (produksi HI) sebesar 5,60 \pm $0,18 \mathrm{mg} / \mathrm{kg}$ dan kadar terendah dengan kode $\mathrm{T} 4$ (produksi AF) sebesar 4,79 $\pm 0,14 \mathrm{mg} / \mathrm{kg}$. Penelitian oleh Angkat et al., (2013) menyatakan hasil pengamatan yang dilakukan pada terasi bermerek menunjukkan bahwa hanya 1 dari 5 sampel yang terdeteksi memiliki kadar timbal yang melebihi ambang batas sebesar 1,80 $\mathrm{mg} / \mathrm{kg}$ dan terasi tidak bermerek juga hanya 1 dari 5 sampel yang terdeteksi memiliki kadar timbal yang melebihi ambang batas sebesar 1,88 $\mathrm{mg} / \mathrm{kg}$. Berdasarkan hasil pemeriksaan tersebut, keberadaan polutan logam timbal di perairan laut dapat meningkatkan kadar timbal pada mikroorganisme (udang) yang akan berimbas pada produk laut setengah jadi seperti terasi. Adanya kandungan timbal pada makanan yang di konsumsi dalam jumlah yang cukup tinggi perlu di waspadai karena dapat meracuni tubuh baik secara akut maupun kronis dan mengganggu kesehatan manusia. Logam timbal yang masuk melalui makanan atau minuman akan menuju faring kemudian dibawa ke saluran cerna. Selanjutnya tersimpan di dalam darah dan akan terakumulasi (Itsnaeni and Susiyanti, 2016).

Kandungan timbal yang terdapat dalam terasi udang dikarenakan bahan baku terasi yaitu udang berasal dari daerah pinggir pantai, dimana pada pantai Banyuwangi terdapat kapal berlabuh (Sari, 2019). Kapal yang berlabuh menghasilkan limbah oli, solar, dan sampah organik yang mengalir ke lautan. Air laut merupakan tempat bermuara buangan limbah dari daratan. Air laut juga sebagai tempat penerimaan bahan pencemaran dari atmosfir. Menurut Ummi et al., (2017) limbah yang mengandung bahan pencemaran dari daratan juga masuk ke dalam ekosistem perairan. Air laut yang telah tercemar masuk ke dalam jaringan tubuh organisme laut seperti fitoplankton, ikan, udang, cumi-cumi, kerang, dan lain-lain. Menurut Komari et al., 
(2013) udang adalah salah satu organisme laut. Saat logam berat masuk ke dalam perairan, sebagian logam berat akan mengendap di dasar laut, sebagian akan terakumulasi di tubuh organisme laut. Biasanya udang mencari makan di dasar perairan, dimana logam berat akan terakumulasi di dasar perairan untuk masuk ke rantai makanan yang kemudian mengontaminasi organisme laut seperti udang (Yusni and Setiani, 2019).

Sifat logam berat yang sulit diuraikan dapat merusak kehidupan organisme laut. Kemudian terjadi penimbunan logam di perairan sehingga sulit dihilangkan. Akibat penimbunan logam di perairan dapat mencemari organisme laut seperti udang yang nantinya diolah menjadi terasi. Terasi merupakan produk hasil fermentasi ikan maupun udang. Terasi biasa digunakan oleh masyarakat sebagai penyedap rasa pada makanan dengan baunya yang khas. Pembuatan terasi dilakukan dengan mencampurkan garam yang cukup banyak, seperti kita ketahui bahwa garam juga termasuk produk perairan dimana harus diwaspadai karena bisa ikut tercemar oleh bahan pencemaran yang ada di perairan (Sihombing and Silalahi, 2018). Bahan baku utama dalam pembuatan terasi udang yaitu udang. Udang dapat mengandung $\mathrm{Pb}$ karena hidup pada lingkungan yang telah tercemar oleh $\mathrm{Pb}$. Udang dengan kadar $\mathrm{Pb}$ melebihi batas maksimum $0,5 \mathrm{mg} / \mathrm{kg}$ dikatakan tidak sesuai dengan SNI 7387:2009 tentang Batas Maksimum Cemaran Logam Berat dalam Pangan.

Pencemaran timbal pada air laut akan memberikan pengaruh terhadap biota laut (udang) yang ada di dalamnya. Menurut penelitian Ummi et al., (2017), kadar Pb dalam tubuh udang dapat dipengaruhi oleh seberapa lama kontak tubuh terhadap lingkungan yang tercemar. Kadar $\mathrm{Pb}$ yang tinggi akan meningkatkan resiko penyakit jika mengkonsumsi terasi yang bahan bakunya adalah udang yang tercemar logam berat. Selain air laut yang dapat mencemari udang, lokasi pengolahan udang yang dekat dengan laut juga berpengaruh terhadap penambahan kadar timbal di udang. Lokasi yang kumuh karena dekat dengan pembuangan limbah rumah tangga serta banyaknya kendaraan yang lalu lalang di sekitar lokasi dapat menambah kadar timbal pada udang yang sedang diolah. Asap dari kendaraan bermotor menyebabkan peningkatan kadar timbal di udara. Penghasil produk terasi maupun orang yang mengolah udang kurang memperhatikan kebersihan dari tempat produksi, alat maupun dirinya sendiri sehingga kadar timbal pada udang dan hasil olahannya yaitu terasi semakin meningkat. Gejala yang ditimbulkan apabila keracunan atau tidak sengaja mengkonsumsi makanan laut yang mengandung logam berat seperti timbal yaitu mual, muntah, sakit perut, kelainan fungsi otak, keguguran, anemia, dan bahkan kematian (Agustina, 2014).

Berdasarkan Tabel 1, terdapat 14 sampel dengan kadar $\mathrm{Pb}$ tidak melewati batas maksimum. Hal ini dapat dikarenakan faktor arah angin yang berlawanan dari tempat sampel dijual. Arah dan kecepatan angin mempengaruhi penyebaran bahan pencemar. Partikel timbal dapat disebarkan angin hingga mencapai jarak 100-1000 km dari sumbernya. Jika penjual makanan berjualan di pinggir jalan raya maka akan lebih rentan terpapar logam timbal dan polutan udara yang kotor. Hasil laut jenis udang perlu diwaspadai karena rentan terhadap pencemaran logam berat (Muthmainnah et al., 2012).

\section{KESIMPULAN DAN SARAN}

\section{Kesimpulan}

Identifikasi kandungan timbal $(\mathrm{Pb})$ didasarkan pada pengujian $\mathrm{pH}$ pada ekstrak sampel makanan terdapat satu sempel makanan positif mengandung $\mathrm{Pb}$ yakni pada sampel terasi udang, dimana kadar terdeteksi sebesar $20 \mathrm{mg} / \mathrm{l}$ $\mathrm{Pb} 2+$ melalui pengukuran test strip $\mathrm{Pb}$. Hasil tersebut melebihi batas maksimum yaitu sebesar $1,0 \mathrm{mg} / \mathrm{kg}$ sesuai dengan peraturan Kepala Badan Pengawas Obat dan Makanan Republik Indonesia Nomor HK.00.06.1.52.4011 tahun 2009.

\section{Saran}

Peneliti selanjutnya diharapkan bisa meneliti logam berat lainnya seperti merkuri, tembaga, kadmium, arsenik, kloronium maupun nikel pada makanan dan hasil laut lainnya. Peran pemerintah dalam pengawasan makanan perlu ditingkatkan agar tidak ada lagi logam berat yang melebihi batas maksimum yang telah ditentukan. Sebaiknya untuk penjual makanan atau industri pangan juga diharapkan mampu menjaga kualitas dan keamanan pangan tersebut. Selain itu, konsumen juga harus memperhatikan makanan yang akan dikonsumsi seperti membeli makanan di tempat yang bersih, tidak membeli makanan di pinggir jalan raya seperti gorengan 
karena akan mudah tercemar oleh logam berat, penjual makanan menggunakan sarung tangan atau pencapit saat mengambil makanan dan kemasan makanan dalam keadaan bersih dan tertutup sehingga dapat mencegah dampak negatif terhadap tubuh.

\section{DAFTAR RUJUKAN}

1] Agustina, T. (2014) 'Kontaminasi Logam Berat Pada Makanan Dan Dampaknya Pada Kesehatan', Teknobuga, 1(1), pp. 53-65.

2] Angkat, I. F., Nurmaini and Hasan, W. (2013) 'Analisa Kandungan Timbal (Pb) Pada Terasi Bermerek Dan Terasi Hasil Olahan Industri Rumah Tangga Yang Dijual Di Beberapa Pasar Tradisional Di Kota Medan Tahun 2013', pp. 1-8.

3] Apriyanti, E. (2018) 'Analisis Kandungan Logam Berat Timbal $(\mathrm{Pb})$ pada Kerang Polymesoda erosa L di Perairan Tanjung Bunga Makassar', IJEEM - Indonesian Journal of Environmental Education and Management, 3(2), pp. 121-131. doi: 10.21009/ijeem.032.03.

4] Badan Pengawas Obat dan Makanan RI (2017) 'Batas Maksimum Cemaran Logam Berat dalam Pangan Olahan', di PerBPOM Nomor 23 tahun 2017, pp. 10-11. Available at: http://standarpangan.pom.go.id.

5] Eshmat, M. E., Mahasri, G. and Rahardja, B. S. (2014) 'Analisis Kandungan Logam Berat Timbal $(\mathrm{Pb})$ Dan Cadmium (Cd) Pada Kerang Hijau (Perna Viridis L.) Di Perairan Ngemboh Kabupaten Gresik Jawa Timur', Jurnal Ilmiah Perikanan dan Kelautan, 7(1), pp. 101-108.

6] Indirawati, S. M. (2017) 'Pencemaran $\mathrm{Pb}$ dan Cd dan Keluhan Kesehatan pada Masyarakat di Kawasan Pesisir Belawan', Jurnal Jumantik, 2(2), pp. 54-60.

7] Itsnaeni, N. and Susiyanti (2016) 'Studi Kadar Pb Pada Makanan Jajanan Dodol Cikal , Di Pasar Banjaran-Adiwerna , Kabupaten Tegal', Jurnal Poltekkes, (36), pp. 203-209.

8] Kirinčič, S. et al. (2019) 'Lead and cadmium in foods/drinking water from Slovenian market/taps: Estimation of overall chronic dietary exposure and health risks', Food Additives and Contaminants - Part A Chemistry, Analysis, Control, Exposure and Risk Assessment, 36(10), pp. 1522-1537. doi: 10.1080/19440049.2019.1628355.
9] Komari, N., Utami, U. B. L. and Febrina (2013) 'Timbal ( $\mathrm{Pb}$ ) dan Kadmium ( $\mathrm{Cd}$ ) pada Udang Windu ( Panaeus monodon ) dan Rajungan ( Portunus pelagicus ) di Perairan Kotabaru Kalimantan Selatan', Prosiding Semiratu FMIPA Universitas Lampung, pp. 281-288.

10] Lee, W. P. et al. (2017) 'Selected Heavy Metals in Penaeus vannamei (White Prawn) in Aquaculture Pond near Likas Lagoon, Sabah, Malaysia', International Journal of Environmental Science and Development, 8(7), pp. 530-533. doi: 10.18178/ijesd.2017.8.7.1010.

11] Muthmainnah, A., Sirajuddin, S. and Najamuddin, U. (2012) 'Pengaruh Lama Waktu Pajan Terhadap Kadar Timbal ( Pb ) Dalam Makanan Jajanan Gorengan Di Lingkungan Workshop Universitas Hasanuddin Makassar', Jurnal Online, (2012), pp. 1-11.

12] Nurjanah, Sembiring, R. and Abdullah, A. (2012) 'Analisis Kandungan Logam Berat Daging Kijing Lokal (Pilsbryoconcha Exilis) Dari Perairan Situ Gede, Bogor', Jurnal Inovasi dan Kewirausahaan, 1(1), pp. 1-7.

13] Pardi, A., Raza'i, T. S. and Viruly, L. (2014) 'Kandungan Logam Berat Timbal ( $\mathrm{Pb}$ ) Pada Udang Putih ( Penaeus Merguiensis ) Berdasarkan Tempat Penangkapan Nelayan Di Teluk Tanjungpinang Kepulauan Riau', pp. 1-10.

14] Perdana, A. P., Sy, E. and Yerizel, E. (2016) 'Analisis Kandungan Timbal Pada Gorengan yang Dijual Sekitar Pasar Ulakan Tapakis Padang Pariaman Secara Spektrofotometri Serapan Atom', FK Unand, 6(3), pp. 490-494.

15] Putri, Y. P., Fitriyanti, R. and Emilia, I. (2019) 'Analisis Kandungan Timbal (Pb) pada Udang Putih (Penaeus merguiensis) sebagai Kontribusi Perhitungan Ocean Health Index (OHI)', Sainsmat: Jurnal Ilmiah Ilmu Pengetahuan Alam, 8(2), p. 58. doi: 10.35580/sainsmat82107202019.

16] Santos, D. B. et al. (2014) 'Effects of Lead in white shrimp (Litopenaeus schmitti) metabolism regarding salinity', Mundo da Saude, 38(1), pp. 16-23. doi: 10.15343/0104-7809.20143801016023.

17] Sari, A. A. K. (2019) 'Analisis Kandungan Timbal $(\mathrm{Pb})$ Pada Hasil Laut Di Pasar 
Tradisional Kabupaten Banyuwangi'.

18] Setiawan, H. (2015) 'Akumulasi dan Distribusi Logam Berat pada Vegetasi Mangrove di Pesisir Sulawesi Selatan', Jurnal Ilmu Kehutanan, 7(1), pp. 12-24. doi: 10.22146/jik.6134.

19] Setyaningrum, E. W. et al. (2018) 'Analisis Kandungan Logam Berat $\mathrm{Cu}, \mathrm{Pb}, \mathrm{Hg}$ Dan Sn Terlarut Di Pesisir Kabupaten Banyuwangi', Prosiding Seminar Nasional Kelautan dan Perikanan IV, (September), pp. 144-153.

20] Sihombing, D. A. and Silalahi, M. I. (2018) 'Pedagang Tentang Bahaya Timbal Di Pasar Tradisional kota Medan Tahun 2018', Jurnal Mutiara Kesehatan Masyarakat, 3(2), pp. 158-168.

21] Siripongvutikorn, S., Asksonthong, R. and Usawakesmanee, W. (2016) 'Evaluation of harmful heavy metal $(\mathrm{Hg}, \mathrm{Pb}$ and $\mathrm{Cd})$ reduction using Halomonas elongata and
Tetragenococcus halophilus for protein hydrolysate product', Functional Foods in Health and Disease, 6(4), p. 195. doi: 10.31989/ffhd.v6i4.240.

22] Ummi, F., Mahmudati, N. and Waluyo, L. (2017) 'Uji Kandungan Timbal ( Pb ) Pada Terasi Udang Dan Ikan Asin Di Palang Kabupaten Tuban', (April), pp. 300-303.

23] Undang-Undang Republik Indonesia Nomor 36 Tahun 2009

24] Yona, D. et al. (2018) 'Distribusi dan Status Kontaminasi Logam Berat pada Sedimen di Sepanjang Pantai Barat Perairan Selat Bali', Torani, 1(2), pp. 21-30.

25] Yusni, E. and Setiani, T. P. (2019) 'Heavy Metal Cadmium (Cd) And Lead (Pb) In Vaname Shrimp (Litopenaeus Vannamei) Collected From Traditional Markets In Medan City, Indonesia', Aquasains, 7(2), p. 707. doi: 10.23960/aqs.v7i2.p707-714. 